http://journal.nafo.int

J. Northw. Atl. Fish. Sci., Vol. 22: 343-355

\title{
Current and Historical Roles of Apex Predators in the Bering Sea Ecosystem
}

\author{
Richard L. Merrick ${ }^{1}$ \\ Protected Species Branch, Northeast Fisheries Science Center \\ National Marine Fisheries Service, NOAA, 166 Water Street \\ Woods Hole, Massachusetts 02543-1097, USA
}

\begin{abstract}
Large population declines (>50\%) since the early-1970s of some eastern Bering Sea and Aleutian Island apex predator populations (Steller sea lions, murres, and kittiwakes) suggest that major changes have occurred in the structure of the Bering Sea ecosystem. One cause of the decline in mammalian and avian predator populations may be a decrease in availability or abundance of preferred prey (e.g. capelin, juvenile walleye pollock). However, adult groundfish biomass has generally been at high levels, and periods of high adult groundfish biomass coincide with periods of decline of sea lion and seabird populations. Adult groundfish may, therefore, be out-competing other predators for their common prey (i.e. small schooling fish). Three factors may have led to increases in adult groundfish biomass in the southeastern Bering Sea, changes in environmental conditions, present commercial fishing practices, and predator release resulting from overharvesting of marine mammals and some fishes during 1955-75. If the decline in whale and fur seal populations during 1955-75 contributed to the current high biomass of groundfish, then marine mammals once (but no longer) exerted a structuring effect on the Bering Sea ecosystem. The current high abundance of piscivorous adult groundfish in the eastern Bering Sea may, therefore, impede the recovery of marine mammal and bird populations to historical levels.
\end{abstract}

Key words: Bering Sea, ecosystem, groundfish, predators, marine mammals, seabirds

\section{Introduction}

The role of marine mammals in structuring pelagic marine ecosystems remains largely unexplored except for limited theoretical considerations (e.g. Estes, 1979; 1994) or in the context of marine mammal-fishery interactions (Alaska Sea Grant, 1983; Harwood, 1983; Beddington et al., 1987; Northridge, 1991). Only in the Southern Ocean has the abundance of marine mammals (i.e. large cetaceans) been considered to influence pelagic ecosystem structure. There, the reduction in whale stocks by commercial exploitation may have contributed to increases in seal and seabird populations through the decreased consumption of krill by whales (Laws, 1985). This proposed relationship points out an unfortunate property of some contem- porary marine ecosystems; they may be fundamentally altered from their historical state by reductions in marine mammal populations. A consideration of the historical roles of marine mammals in the Bering Sea may provide a better understanding of the work of Livingston (1994) who calculated the "species richness" of the eastern Bering Sea (EBS) pelagic fish consumers guild to be near 1.0 (i.e. little diversity) because of the current dominance of the pelagic ecosystem by walleye pollock (Theragra chalcogramma). Prey consumption by marine mammals is presently so small that they likely have little effect on the EBS ecosystem (Livingston, 1993; Perez and McAllister, 1993), however, the EBS large whale and pinniped numbers were far larger historically than currently (Small and DeMaster, 1995). Has the dominance of

\footnotetext{
1 Work reported in this paper was completed as part of a doctoral dissertation at the University of Washington, School of Fisheries, and conclusions reached may not represent those of the National Marine Fisheries Service, NOAA.
} 
walleye pollock always been a feature of the EBS or is this dominance a result of the reduced marine mammal populations in the ecosystem?

This question may be crucial to the search for the cause of the declines of piscivorous marine mammals and birds in the EBS, Aleutian Islands and Gulf of Alaska (Table 1). Harvests of large cetaceans (blue, Balaenoptera musculus; fin, Balaenoptera physalus; sei, Balaenoptera borealis; humpback, Megaptera novaeangliae; northern right whales, Eubalaena glacialis) so reduced their abundance that by 1976, commercial whaling for these species was terminated in the North Pacific Ocean by the International Whaling Commission. These whale populations have shown little recovery since then (Barlow et al., 1995; Small and DeMaster, 1995). The EBS population of northern fur seals (Callorhinus ursinus) began to decline in the mid1960 s due largely to harvests of adult females (York and Kozloff, 1987). The decline abated briefly in the mid-1970s but began again and continued through the early-1980s (NMFS, 1993). The population has since stabilized and may be increasing somewhat. However, it remains listed as depleted under the US Marine Mammal Protection Act.
A second set of declines in apex predators began in the mid-1970s. For the mammals, Steller sea lion (Eumetopias jubatus) numbers remained high from the 1950s through the early 1970s, and then began a decline which has continued to the present (NMFS, 1995). Steller sea lions in western Alaska (the Bering Sea, Aleutian Islands and Gulf of Alaska) are presently listed as endangered under the Endangered Species Act. Harbor seals (Phoca vitulina) may have declined since the 1970s in the eastern Aleutian Islands (that portion of the Aleutian Islands proximate to the EBS). For the birds, declines have also been recorded for red-legged kittiwakes (Larus brevirostris), black-legged kittiwakes (Larus tridactyla), common murres (Uria aalge), and thick-billed murres (Uria lomvia) in the EBS and eastern Aleutian Islands (Hatch, 1993; Piatt and Anderson, 1996).

A variety of causes for the mammal and bird declines since the 1970s have been considered, and many have been eliminated as likely causes of the overall decline (e.g. redistribution, subsistence hunting, commercial harvests, other shooting, entanglement in marine debris, pollutant effects and predation; NMFS, 1995). The consensus among

TABLE 1. Recent records and trends in abundance, and current management listing status of selected North Pacific Ocean (NPO), eastern Bering Sea (EBS), Aleutian Island (AI), and Gulf of Alaska (GOA) apex predators. Cetacean and pinniped information from Small and DeMaster (1995) and Barlow et al. (1995). Seabird data from Hatch (1993) and Piatt and Anderson (1996).

\begin{tabular}{|c|c|c|c|}
\hline Species & Area & Population trend & Listing status \\
\hline \multicolumn{4}{|l|}{ Cetaceans } \\
\hline Blue whale & NPO & Low and trend unknown & Endangered \\
\hline Fin whale & NPO & Low and trend unknown & Endangered \\
\hline Sei whale & NPO & Low and trend unknown & Endangered \\
\hline Humpback whale & NPO & Low but increasing & Endangered \\
\hline Northern right whale & NPO & $<5 \%$ of historical; trend unknown & Endangered \\
\hline \multicolumn{4}{|l|}{ Pinnipeds } \\
\hline Steller sea lions & $\mathrm{BS} / \mathrm{AI} / \mathrm{GOA}$ & $<20 \%$ of historical; declining & Threatened $^{1}$ \\
\hline Pacific harbor seals & $\mathrm{BS} / \mathrm{AI} / \mathrm{GOA}$ & Low GOA; BS/AI unknown & Not listed \\
\hline Northern fur seals & BS & $<50 \%$ of historical; stable & Depleted \\
\hline \multicolumn{4}{|l|}{ Seabirds } \\
\hline Red-legged kittiwakes & BS & Reduced and declining & Candidate \\
\hline Black-legged kittiwakes & BS & Reduced and declining & Not listed \\
\hline Common murres & $\mathrm{BS} / \mathrm{AI} / \mathrm{GOA}$ & Declines in all areas & Not listed \\
\hline Thick-billed murres & BS & Declining & Not listed \\
\hline
\end{tabular}

1 Western stock listed by National Marine Fisheries Service as endangered in June 1997. 
active researchers is that at least the Steller sea lion declines have resulted from changes in the availability of preferred prey (Merrick et al., 1987; D. Calkins, ADF \& G, Anchorage, AK, unpubl. data, 1988; Loughlin and Merrick, 1989; Alverson, 1991; Springer, 1992; Alaska Sea Grant, 1993; Decker et al., 1995; Merrick, 1995; Hunt et al., 1996; Piatt and Anderson, 1996). Food habit studies suggest that sea lions, harbor seals, and piscivorous seabirds have historically relied on a variety of small $(<35 \mathrm{~cm})$, schooling pelagic fish as prey (Pitcher, 1980, 1981; Decker et al., 1995; Hunt et al., 1996; Merrick and Calkins, 1996; Piatt and Anderson, 1996). During these predator population declines their diet changed and is now heavily focused on a single prey (usually walleye pollock). Some prey (like capelin, Mallotus villosus), which were commonly consumed by most of these species prior to the predator declines, disappeared from their diets in the late 1970 s (D. Calkins, ADF\&G, Anchorage, AK, unpubl. data, 1988; Decker et al., 1995; Piatt and Anderson, 1996). For Steller sea lions and common murres, the areas or periods where their diets were more diverse (i.e. contained more prey species) appeared to have stable populations (Merrick, 1995; Merrick and Calkins, 1996; Piatt and Anderson, 1996).

Evidence suggests that some key prey species, such as juvenile walleye pollock and capelin were less available to marine mammals and birds during the period(s) of their population declines than prior to the declines. Juvenile walleye pollock abundance has been highly variable, but has generally shown a downward trend since the early-1980s (Fig. 1). Despite a few strong year-classes in the period, years remained when few juvenile pollock were available. This would reduce predator survival unless alternative prey were available (the "high risk" feeding strategy of Sinclair et al., 1994). The abundance of other prey, such as capelin, Pacific sand lance (Ammodytes hexapterus), Pacific herring (Clupea harengus), and small demersal fish, was highly variable from the late-1970s to the present. Abundance of Pacific herring in the EBS was high in the early-1960s (1 million tons or greater), then declined to very low levels in the 1970 s $(<0.1$ tons), rose in the early-1980s to around 0.6 tons, and declined again to around 0.1 tons in 1990 (Wespestad, 1991; Bakkala, 1993). Capelin abundance was high in the EBS in the 1970s, but has since declined (V. Wespestad, National Marine Fisheries Service, (NMFS), Seattle, WA, pers. comm., 1994; A. Zolotov, Pacific Research Institute of Marine

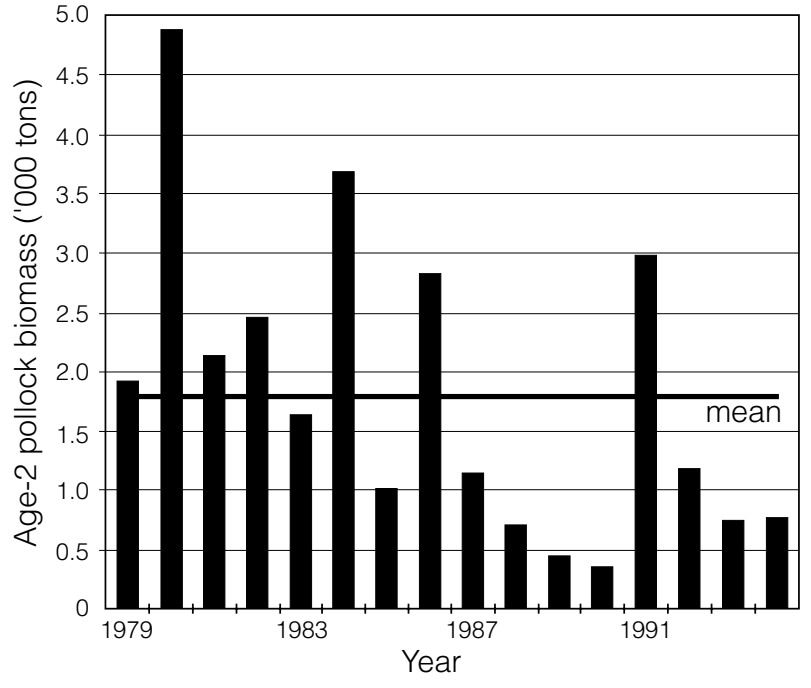

Fig. 1. Age 2 walleye pollock biomass by survey year for 1979 to 1994. Data from Wespestad (1994).

Fisheries and Oceanography, Vladivostok, Russia, pers. comm., 1994). Abundance of some other small prey species (e.g. eulachon (Thaleichthys pacificus), sculpins, and eelpouts (Lycodes spp.)) also appeared to decrease from the late-1970s to the mid1980s (Bakkala, 1993; Fritz et al., 1993). In addition, trawl data collected in the Gulf of Alaska at Pavlof Bay (Alaska Peninsula) during 1972-92 indicated that the abundance of shrimp and some small forage and demersal fish species (e.g. capelin, Pacific sandfish (Trichodon trichodon)) decreased abruptly around 1978-82; similar changes have been found in a preliminary analysis of other areas of the Aleutian Islands and Gulf of Alaska (Anderson et al., MS 1995). One major prey of sea lions and seabirds which has not declined, however, is Atka mackerel (Pleurogrammus monopterygius), whose population biomass in the Aleutian Islands increased from 0.2 tons in 1980 to 0.6 tons in 1994 (Lowe and Fritz, 1995).

If the declines in some mammalian and avian fish predators have been induced by changes in abundance of their prey, then the cause(s) of these changes must be identified before measures can be enacted to reverse the declines. In this review, the hypothesis is presented that the decline in prey abundance is a result of a change in the EBS trophic structure. That is, the current high population of groundfish (e.g. adult walleye pollock) has resulted in a systematic reduction of the abundance of marine mammal and seabird prey. Three additional hypotheses are discussed which may explain the 
high abundance of adult groundfish and low abundance of forage fish (e.g. juvenile pollock, capelin) viz effects of an oceanic regime shift, commercial fisheries, and a trophic cascade resulting from the depletion of some marine mammal and fish populations. Finally, brief comments are made on the implications of these hypotheses to recovery of apex predator populations in the eastern Bering Sea.

\section{The Groundfish Predation Hypothesis}

A change in the upper trophic levels of the EBS may have begun in the mid-1960s. Bakkala (1993) estimated the biomass of the EBS groundfish complex $^{2}$ increased (with some fluctuation) from around 4.8 tons in 1965 to 15.2 tons in 1984. Most of the change in groundfish biomass was produced by increases in adult pollock, whose biomass grew from around 2 tons in 1965 to 13.1 tons in 1984 (Bakkala, 1993; Wespestad, 1994; Fig. 2). The increase in pollock biomass initially resulted from five aboveaverage year classes spawned during 1965-69. Adult pollock biomass peaked around 1972 and then declined through the late-1970s (Fig. 2). Pollock abundance began to increase again in the early-

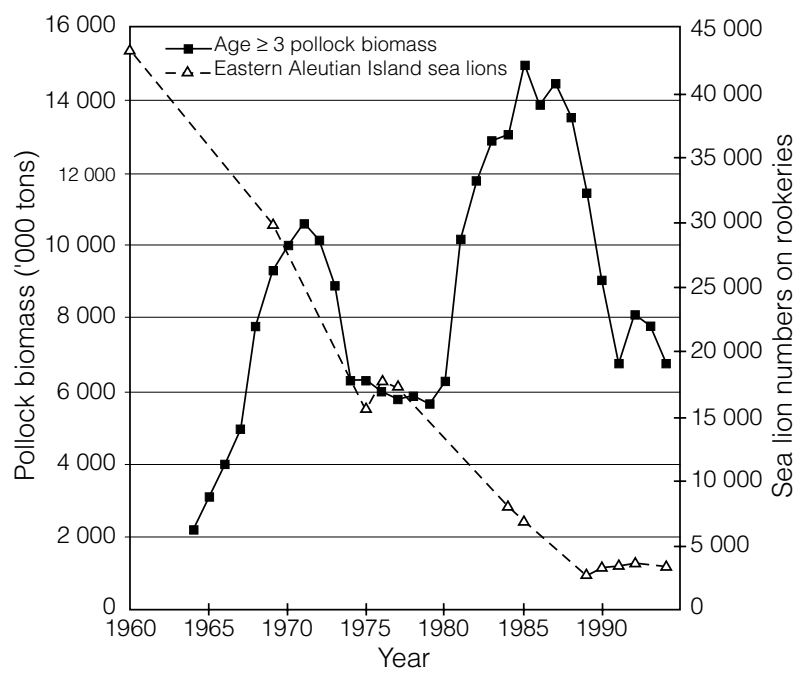

Fig. 2. Eastern Bering Sea adult walleye pollock biomass and Steller sea lion eastern Aleutian Island trend rookery numbers for 1960-94. Pollock data from Wespestad (NMFS, Alaska Fisheries Science Center, Seattle, WA, pers. comm. 1995). Sea lion data from NMFS (1995). 1980s due to several strong year-classes spawned in the 1978-84 period. Pollock biomass peaked again around 1985, and then began a decline through 1994.

The 1972 and 1985 peaks in adult pollock biomass coincide with the two periods of decline in eastern Aleutian Island Steller sea lion numbers (Fig. 2), while the low points in pollock abundance (late-1970s and early-1990s) coincide with periods of relative stability in sea lion numbers. An inverse relationship may, therefore, exist between adult pollock abundance and sea lion declines. This relationship may lie in the competition between groundfish and sea lions (as well as some seabirds) for common prey. Adult pollock consume considerable amounts of fish, and in particular consume many of the same forage fish (e.g. juvenile pollock, herring) that marine mammals and seabirds eat (Wespestad and Fried, 1983; Livingston, 1991, 1993; Livingston et al., 1993). The five-fold increase in adult pollock biomass during 1962-72 must have significantly increased the amount of fish consumed by pollock once the pollock reached adulthood (beginning around 1969). Subsequently, the continued high abundance of adult groundfish compared to the early-1960s may have resulted in a chronic depletion of alternate fish prey available with mammalian and avian predators, which in combination with the highly variable juvenile pollock abundance may be a major factor driving the declines of non-fish, apex predators in the EBS.

This hypothesis is not without parallels in other marine ecosystems. A similar hypothesis has been proposed to explain the Arctic cod (Gadus morhua), Atlantic herring (Clupea harengus), capelin (Mallotus villosus), harp seal (Phoca groenlandica), and seabird declines which occurred in the Barents Sea in the late-1980s (Hamre, 1994; Gjøsœter, 1995; Kjellqwist et al., 1995). Herring were overexploited from the early-1970s onwards, and this created an imbalance in predator (cod) - prey (herring/capelin) relationships. In the 1970s and early-1980s the imbalance was not obvious because cod (at relatively low stock sizes) could feed on capelin (which was then abundant). In the mid1980 s, favorable recruitment conditions existed for both cod and herring. Herring stocks were

\footnotetext{
2 This includes gadids, Atka mackerel, flatfish, and rockfish. It does not include the biomass of some of the fish species which are major prey for sea lions and other top-predators. For example, Pacific herring biomass was estimated to be a least 1-1.2 tons at the beginning of the 1960s (Wespestad, 1991; Bakkala, 1993)
} 
not sufficiently large to capitalize on conditions. Cod, whose recruitment is not dependent on adult stock size, produced three strong year-classes. With a lack of juvenile herring as prey, the rapidly growing cod stock fed on other available prey species, including its own offspring. This was followed in the late-1980s by the decline of cod, capelin, seabird, and seal populations. A nearly total failure of the 1986-88 year-classes of harp seals was observed (Anon., MS 1992, MS 1994) and substantial declines (>50\%) were recorded in numbers of common murres and Atlantic puffins (Fratercula arctica) throughout the $1980 \mathrm{~s}$ at major colonies in Norway (Anon., 1995). Similar events may have occurred in the EBS with the exception that the predator (walleye pollock) population has not collapsed.

If the decline in some EBS marine mammal and bird populations resulted from competition with fish predators, then what produced this increase in groundfish abundance? Unlike most other gadids, walleye pollock have a weak stock-recruitment relationship (Myers and Barrowman 1996). Recruitment must, therefore, be a result of other factors such as oceanic conditions and predation. It is proposed here that three factors may together have contributed to the increase in adult groundfish-an oceanic regime shift in 1976-77, commercial fisheries, and a trophic cascade resulting from the depletion of large whales, fur seals, and some fin fish in the 1960 s and 1970 s.

\section{The Oceanic Regime Shift Hypothesis}

The hypothesis has been proposed that cyclic oceanic conditions in the subarctic North Pacific Ocean (including the EBS, Aleutian Islands, and Gulf of Alaska) produce significant shifts in the species composition of its constituent ecosystems. Shifts between warm and cool periods appear to occur on a decadal or greater (e.g. 18.6 year) frequency in the North Pacific Ocean (Royer, 1989; Hollowed and Wooster, 1992; Royer, 1993; Trenberth and Hurrell, 1995; Wooster and Hollowed, 1995). The most recent shift in the physical oceanography of the subarctic North Pacific Ocean occurred around 1976-77 (Royer, 1989; Tabata, 1989; Kerr, 1992; Francis and Hare, 1994; Trenberth and Hurrell, 1995). Evidence exists that the shift increased primary and secondary productivity in the North Pacific Ocean (Venrick et al., 1987; Brodeur and Ware, 1992; Venrick, 1995;
Polovina et al., 1995). General relationships between regime shifts and year class strength of fishes have also been hypothesized for groundfish (Hollowed and Wooster, 1995) and salmonids (Francis and Hare, 1994; Hare and Francis, 1995). Indeed, the biomass of a variety of fish and cephalopods did increase during the 1976-77 regime shift (Beamish and Boullion, 1993, 1995; Beamish, 1994; Francis and Hare, 1994; Brodeur and Ware, 1995; Hare and Francis, 1995; Hollowed and Wooster, 1995; Polovina et al., 1995). However, declines were also observed in stocks of some other finfish (e.g. capelin; Anderson et al., MS 1995) and crustaceans (e.g. pandalid shrimps, Albers and Anderson, 1985; king crab, Otto, 1989 and Kruse, 1993). These declines have been attributed to a combination of direct effects of ocean warming coupled with increased predation (Albers and Anderson, 1985; Piatt and Anderson, 1996).

Declines of Steller sea lions, kittiwakes, and murres spread throughout southwest Alaska (the Aleutian Islands and Gulf of Alaska) at approximately the same time as the 1976-77 regime shift suggesting that there may be a link between changes in oceanographic conditions and productivity of upper trophic levels. However, large Steller sea lion declines also occurred in the eastern Aleutian Islands and Pribilof Islands during the early-1970s prior to this regime shift (Braham et al., 1980). Furthermore, the life history and foraging characteristics of marine mammals and seabirds suggest that regular decadal shifts in fish biomass should not produce large $(<50 \%)$, chronic declines in their populations. Sea lions and seabirds have the features of classic "K-selected" species-low mortality rates, slow development, delayed reproduction, few offspring, high parental investment in offspring, long lives, and long generation times. A species with such a life history is expected to maintain a relatively stable population size and to have evolved in a relatively stable environment (Cole, 1954; Pianka, 1970; Stearns, 1976; Estes, 1979). Such a species cannot rapidly recover from low population sizes and, while the population size is low, it is vulnerable to extinction from a variety of factors (e.g. predation and disease). Moreover, most of the declining EBS top predators are euryphagous indicating that they have adapted to an environment where prey abundance changes (at least at some time scale, decadal or otherwise). Euryphagy allows them to switch as prey abundance changes and should decouple predator abundance from the abun- 
dance of any single prey. If the 1976-77 regime shift was insufficient in itself to elicit the major changes observed in marine mammal and bird populations then something else must have occurred.

\section{The Commercial Fisheries Hypothesis}

Commercial fisheries target adults of several of the most important prey species of EBS top predators and as a result have been a suspected cause of the decline in prey availability (Braham et al., 1980; Merrick et al., 1987; Loughlin and Merrick, 1989; Ferrero and Fritz, 1994). However, because much of the decline in marine mammal and bird populations occurred during times when groundfish abundance was high, it is difficult to substantiate a relationship between fishery removals and predator declines. Localized depletion by the fisheries remains a possibility, but tests for localized prey depletion, which were conducted by comparing changes in sea lion abundance with nearby fishery removals of pollock, have produced inconclusive results (Loughlin and Merrick, 1989; Ferrero and Fritz, 1994). The lack of evidence from this research may, however, be due to the lack of appropriately scaled data on catch or a lack of data on fish abundance prior to fishing (Ferrero and Fritz, 1994).

Fisheries (except the herring fishery) typically do not target on the small fish prey that marine mammals and seabirds consume. Still, fisheries could have reduced the abundance or availability of prey by disrupting fish behavior as nets pass through schools and from by-catch of non-commercial prey species. Roe fisheries could have reduced the number of age- 0 and age- 1 pollock available to marine mammals and birds by reducing the number of spawners, by disrupting spawning behavior, and by removing a disproportionate number of female fish. Sampson (Hatfield Marine Science Center, Oregon State Univ., Newport, OR, unpubl. data, 1995) found that the winter pollock roe fishery catches in the EBS was significantly correlated with sea lion declines in the Aleutian Islands. These second-order fishery effects may have substantial impacts on North Pacific Ocean ecosystems and should be the subject of further research.

\section{The Trophic Cascade Hypothesis}

If a change in the EBS ecosystem began in the 1960 s, then both the 1976-77 regime shift and current fisheries practices would have occurred after the change was initiated and thus by themselves would be insufficient to explain the change. The proposal here is that a "trophic cascade" (Carpenter et al. 1985) was initiated by the depletion of large whales, northern fur seals, Pacific herring, and Pacific ocean perch (Sebastes alutus) during 195575. This depletion led to increased zooplankton availability and reduced predation on juvenile groundfish, both of which would have ultimately increased the carrying capacity of groundfish. A similar hypothesis has been considered previously by Bakkala et al. (1987) but was discounted because releases of prey caused by reduced Pacific herring and Pacific ocean perch populations would have been insufficient to account for the ultimate adult pollock biomass increase. However, Bakkala et al. (1987) did not consider that only juvenile pollock needed to benefit; compared to the juvenile, adult pollock diets are more diverse and include a larger amount of fish (Livingston, 1991; Livingston et al., 1993). They also did not consider that the substantial whale harvests during the period would also release juvenile pollock prey, or that reductions in both whale and fur seal abundance would reduce predation on juvenile pollock. The life-history characteristics of pollock (an "r-selected" species) are such that they could rapidly exploit such a change in their environment.

Prior to the 1960s, the EBS ecosystem may have been stabilized by the presence of relatively large populations of large whales, seals, sea lions, herring and Pacific ocean perch. During 1955-75 many of these species were simultaneously reduced to low levels by exploitation (Fig. 3). During this period, 77603 whales (33 992 fin, 38607 sei, 5004 humpback) were harvested (Fig. 3; D. Rice, NMFS, Seattle, WA, unpubl. data). Most of these whales came from the EBS, Aleutian Islands, Gulf of Alaska, and north Pacific Ocean waters immediately south of these areas. Fin whale takes would have most heavily influenced the EBS shelf, Aleutian Islands (which could have also influenced the eastern Bering Shelf through transport within the EBS), and coastal waters of the Gulf of Alaska. Declines in herring and Pacific ocean perch biomasses occurred simultaneous to the fin whale takes. Eastern Bering Sea Pacific adult (ages 3-9) herring biomass declined from 0.9 tons in 1960 to 0.1 tons in 1975 (Wespestad, 1991). Eastern Bering Sea adult (age 9+) Pacific ocean perch biomass fell from 0.1 tons in 1960 to 0.05 tons in 1975, while in the Aleutian Islands biomass fell from 0.5 tons in 1960 to 0.1 tons in 1975 (Ito and Ianelli, 1994). Finally, the EBS (Pribilof Islands) stock of northern fur seals which was estimated to comprise 2.1 million animals 

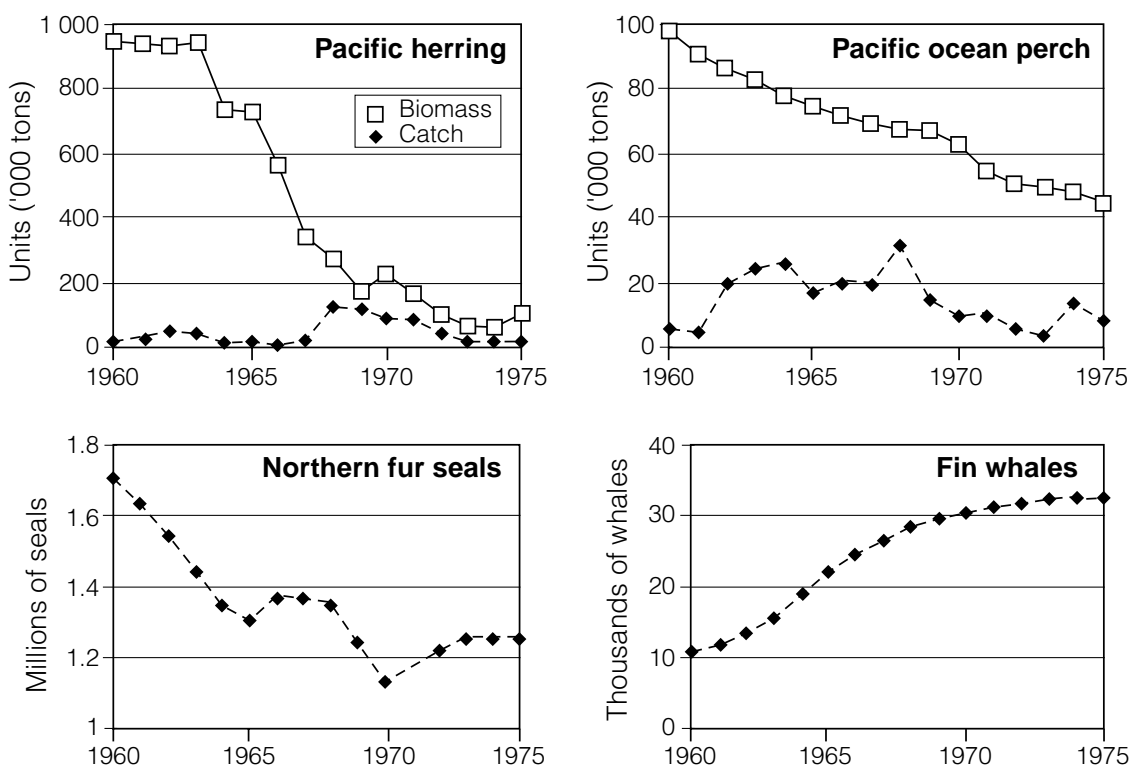

Fig. 3. Cumulative biomass and catch of Pacific herring and Pacific ocean perch along with abundance of northern fur seals and cumulative harvests of fin whales from North Pacific Ocean (eastern Bering Sea) from 1960 to 1975. Fish catches in thousands of metric tons shown with diamonds, and biomasses with squares. Abundance of fur seals in millions shown with diamonds, and cumulative catches of fin whales in thousands shown with diamonds.

during 1949-51 (Kenyon et al., 1954) fell to 1.7 million animals in 1960, 1.1 million in 1970, and 1.3 million in 1975 (Fig. 3; NMFS/NMML, Seattle, WA, unpubl. data). Declines through the early1970 s resulted from the harvesting of approximately 23000 adult females a year during 1956-68 (York and Hartley, 1981).

The timing of these marine mammal and fish removals bracketed the period in which pollock biomass increased from 2 tons in 1965 to $10-12$ tons in 1971, due to the above-average year classes spawned during 1965-69. If there is a relationship between removals of the marine mammals and fish, and the increase in pollock biomass, it may be due to both the diet overlap between whales and fish, and northern fur seal predation on juvenile pollock. Juvenile and adult pollock, herring and Pacific ocean perch, and fin, sei and humpback whales, all consume euphausiids (Thysanoessa spp.) and calanoid copepods as major prey in the north $\mathrm{Pa}$ cific Ocean (Tomlin, 1957; Takahashi and Yamaguchi, 1972; Cooney et al., 1980; Smith, 1981; Gaskin, 1982; Walline, 1983; Dwyer et al., 1986; Livingston, 1991; Livingston et al., 1993). Northern fur seals, on the other hand, have tradi- tionally fed heavily on walleye pollock in the EBS (Perez, 1986; Perez and Bigg, 1986; Sinclair et al., 1994, 1996) and, at least in the 1980s and 1990s, most of this consumption was either age- 0 and age1 pollock (Sinclair et al., 1996).

How much walleye pollock could the surplus zooplankton prey and reduced predation have supported? A gross estimate of the scale of potential biomass release in the EBS is shown in Table 2. By 1970, the reduction of fin whales, Pacific herring and Pacific ocean perch in the EBS and Aleutian Islands could have released 1.4 tons (EBS only) to 2.8 tons (EBS and AI) of zooplankton prey a year. An age-1 pollock consumes around $0.32 \mathrm{~kg}$ of prey per year (Livingston et al., 1993; Wespestad, 1994; Merrick, 1995). Assuming complete diet overlap and compensation, the release of prey would be sufficient to feed 4.3 to 8.9 billion age- 1 pollock for a year.

Assuming that $67 \%$ of the fur seal prey were pollock (Perez, 1994), 343000 tons of the 512000 tons of prey released by the reduced fur seal population would be pollock (mostly age- 0 or age1). If all were age- 1 pollock, at $0.12 \mathrm{~kg}$ per fish, 
TABLE 2. Predator biomass removals and annual prey biomass release from harvests of fin whales, Pacific herring, Pacific ocean perch and northern fur seals through 1970 for the eastern Bering Sea (EBS) and Aleutian Islands (AI). BW indicates feeding rate as equal to body weight for year. Northern fur seal and fin whale estimates of feeding from Perez (1994). Prey types are zooplankton (Z) and fish (F).

\begin{tabular}{|c|c|c|c|c|c|c|c|}
\hline \multirow[b]{2}{*}{ Species } & \multirow[b]{2}{*}{ Area } & \multicolumn{2}{|c|}{ Biomass } & \multirow{2}{*}{$\begin{array}{l}\text { Feeding } \\
\text { rate } \\
\text { (kg/day) } \\
\text { (B) }\end{array}$} & \multirow{2}{*}{$\begin{array}{l}\text { Days } \\
\text { feeding } \\
\text { in area } \\
\text { (C) }\end{array}$} & \multirow{2}{*}{$\begin{array}{l}\text { Biomass } \\
\text { release } \\
(\text { tons }) \\
(\mathrm{A} * \mathrm{~B} * \mathrm{C})\end{array}$} & \multirow[b]{2}{*}{$\begin{array}{l}\text { Prey } \\
\text { type }\end{array}$} \\
\hline & & $\begin{array}{c}\text { Number } \\
A\end{array}$ & $\begin{array}{c}\text { Biomass } \\
\text { (tons) }\end{array}$ & & & & \\
\hline \multirow[t]{2}{*}{ Fin whale } & EBS & 4000 & 196000 & 1265 & 120 & 607200 & $\mathrm{Z} / \mathrm{F}$ \\
\hline & EBS/AI & 11000 & 539000 & 1265 & 120 & 1669800 & $\mathrm{Z} / \mathrm{F}$ \\
\hline Northern fur seal & EBS & 569000 & 24467 & 5 & 180 & 512100 & $\mathrm{~F}$ \\
\hline Pacific herring & EBS & - & 721000 & BW & 240 & 721000 & $\mathrm{Z}$ \\
\hline \multirow[t]{2}{*}{ Pacific ocean perch } & EBS & - & 35300 & BW & 240 & 35300 & $\mathrm{Z}$ \\
\hline & EBS/AI & - & 419300 & BW & 240 & 419300 & $\mathrm{Z}$ \\
\hline Minimum & EBS only & & 976767 & & & 1875600 & \\
\hline Maximum & $\mathrm{EBS} / \mathrm{AI}$ & & 1703767 & & & 3322200 & \\
\hline
\end{tabular}

this could remove predation on 2.9 billion age-1 pollock. Based on cohort analysis estimates of age1 biomass from Wespestad (1994) and an average size for an age- 1 fish of $0.12 \mathrm{~kg}$, the average number of age-1 pollock in the EBS for 1979-94 was 10.6 billion fish. Nine of the year-classes during the period were less than 11.7 billion fish. Thus, the released zooplankton (without the pre-existing levels of prey) and reduced predation pressure could by themselves have supported juvenile pollock year-classes during 1965-69 that were similar in size to recent recruitment.

\section{A Chronology of Groundfish Predation Effects}

The low EBS walleye pollock biomass at the beginning of the 1960s was composed mostly of older fish (Bakkala et al., 1987). During the late1960 s, the combination of increased zooplankton availability, reduced fur seal predation, and low cannibalism would have benefitted juvenile pollock more than adult pollock because adult pollock biomass was low. As the 1965-69 year-classes recruited to the population, adult pollock biomass increased. Unlike juveniles, adult pollock consume considerable amounts of fish as well as crustacea (Livingston, 1991; Livingston et al., 1993), and the increase in adult biomass must have increased the amount of fish and zooplankton consumed. Pollock are semi-demersal as adults and would be ideally located to prey upon small fishes associated with the bottom, as well as pelagic fishes like juvenile pollock, capelin and herring (Wespestad and Fried, 1983; Livingston, 1991, 1994; Livingston et al., 1993). Increased pollock predation would have reduced the biomass of forage fish.

Although no data are available on forage fish abundance for the 1970-75 period, it was during this period that the first well documented declines in Steller sea lion abundance occurred (Braham et al., 1980). This occurred in the eastern Aleutian Islands, the major sea lion habitat associated with the EBS. The impact of pollock predation on forage fish populations would have been short-lived because EBS pollock biomass began to decline almost immediately after reaching a peak in 1971 . The eastern Aleutian Island sea lion decline appeared to abate (Fig. 2) soon after the EBS pollock population began to decline. Thus, it is possible that competition with pollock may have exacerbated the eastern Aleutian Island sea lion declines induced by large incidental takes in the "foreign" groundfish fishery and direct takes in the crab fishery (Merrick et al., 1987; Perez and Loughlin, 1991).

Heavy fisheries exploitation of the stock during the 1970s (compared to the 1960s and 1980s) may explain the decline in pollock biomass during 1972-80. Exploitation rates through the 1960s were 
$14 \%$ or less of the exploitable stock, but increased to as high as $25 \%$ in the 1970 s. By the 1980 s, the rate had returned to $\leq 17 \%$. It is notable, however, that the EBS adult pollock population never declined to the size (Fig. 2) estimated for the mid-1960s.

The 1976-77 oceanic regime shift then occurred at a time when conditions were similar to those during 1965-69. Whale, fur seal, Pacific herring and Pacific ocean perch numbers were all low, so surplus zooplankton remained available and predation was reduced (Fig. 3). Adult pollock abundance was at moderately low levels (Fig. 2), so cannibalism was reduced. These conditions, overlaid on the template of favorable ocean conditions, resulted in several strong year-classes for many groundfish species during 1978 through 1984. Biomass of adult pollock, as well as Pacific cod and the flatfishes, increased to near-record levels. Eastern Bering Sea adult pollock biomass rose from around 6 tons in 1980 to nearly 15 tons in 1985 . Despite these increases in adult groundfish biomass, sea lion and seabird populations decreased significantly, and a lack of prey may have caused the decreases. Capelin declined and subsequently disappeared from fur seal and seabird diets. Pacific herring in the EBS, which had increased in the early-1980s due to strong yearclasses in 1976-77, returned to low 1970s level. Finally, juvenile pollock abundance declined to progressively lower levels after 1984 (Fig. 1), even though it constituted a larger portion of fur seal and seabird diets than in the 1970s (Hunt et al., 1996; Piatt and Anderson, 1996; Sinclair et al., 1996).

Adult pollock abundance declined after 1985 to around 6-8 tons in the mid-1990s (Fig. 2). Steller sea lion numbers in the eastern Aleutians stabilized around 1990 (NMFS, 1995). The stabilization of Steller sea lion numbers may have been due to the availability of small pollock from the 1989 yearclass coupled with the increased availability of a number of other prey. Analysis of 89 sea lion scats collected during 1990-93 in the eastern Aleutian Islands found small forage fish (capelin, sand lance, herring), salmon, Atka mackerel, and a variety of small demersal fish (e.g. sculpins) in the diet in addition to juvenile pollock (Merrick, 1995). A collection of 40 scats from 1985 found only pollock and salmon in the diet. The difference in diets between 1985 and 1990-93 suggests that a greater variety of prey was available in the 1990s when adult pollock biomass was reduced (Merrick et al., 1997).

\section{Potential for Recovery of Eastern Bering Sea Marine Mammal and Bird Populations}

A reduction in $\mathrm{K}$-selected species (e.g. marine mammal and seabird) abundance coupled with an increase in abundance of r-selected species (e.g. pollock) may shift ecosystem stability toward greater variability in population sizes (Dickie, 1973; Margalef, 1975; Estes, 1979; Ray, 1981; Allen, 1985; O'Neill et al., 1986). This variability makes fishery stocks "progressively less amenable to conventional management and progressively more vulnerable to the uncontrollable and largely unpredictable forces of the environment" (Apollonio, 1994). This is essentially what may have occurred in the EBS since the 1950s. Prior to exploitation, a suite of $\mathrm{K}$-selected species (large whales, fur seals, sea lions, harbor seals, ice seals, seabirds and some fish) may have exerted considerable control over the Bering Sea ecosystem. Consumption of zooplankton and predation on groundfish by these species may have kept juvenile groundfish abundance at low levels, which restricted the possible stock size of adult groundfish. This limited the impacts of groundfish on forage fish populations. Reductions in the populations of some K-selected species during 1955-75 may have triggered a sequence of events which in combination with oceanographic changes and current fishing practices (low exploitation rates) may have produced sharp increases in adult groundfish biomass. The resulting increased consumption of small fish by adult groundfish may have reduced the alternate prey available to other predators and coupled with highly variable juvenile pollock abundance may have led indirectly to the recent declines in some EBS marine mammal and seabird species. Thus, the large increases in groundfish biomass that occurred in the EBS after the early-1960s while good for commercial groundfish fisheries, may have been to the detriment of other members of the ecosystem. Conditions may remain unfavorable for sea lions and seabirds so long as groundfish populations remain high. Moreover, if groundfish in the EBS have occupied the feeding niche formerly filled by whales, then recovery of whale populations may remain slow.

Clearly, the hypothesis that competition with groundfish is contributing to the Steller sea lion and seabird declines remains an open issue suggesting further testing is warranted. One immediate merit 
to the hypothesis may be that testing could disclose previously unconsidered management actions to reverse the EBS declines of Steller sea lions and seabirds.

\section{Acknowledgments}

My thanks to Dee Boersma, Charles Fowler, and Robert Francis who started me thinking about the temporal aspects of the Bering Sea ecosystem dynamics. P. D. Boersma, P. Boveng, H. Braham, J. Breiwick, G. Duker, C. Fowler, R. Francis, L. Fritz, J. Lee, T. Loughlin, P. Livingston, S. Mello, T. Quinn, E. Sinclair, M. Strick, G. VanBlaricom, and two anonymous critics reviewed early drafts of this manuscript. This manuscript was originally written as part of a Ph. D. dissertation at the School of Fisheries, University of Washington, Seattle.

\section{References}

ALASKA SEA GRANT. 1983. Proceedings of the workshop on biological interactions among marine mammals and commercial fisheries in the southeastern Bering Sea, October 18-21 1983. Alaska Sea Grant Rep., 84-1, 300 p.

1993. Is it food? Addressing marine mammal and seabird declines. Workshop summary. Alaska Sea Grant Rep., 93-01, 59 p.

ALBERS, W. D. and P. J. ANDERSON. 1985. Diet of Pacific cod, Gadus macrocephalus, and predation on the Northern pink shrimp, Pandalus borealis, in Pavlof Bay, Alaska. Fish. Bull. U.S., 83: 601-610.

ALLEN, P. M. 1985. Ecology, thermodynamics, and selforganization: Towards a new understanding of complexity, p. 3-26. In: Ecosystem Theory for Biological Oceanography. R. E. Ulanowicz and T. Platt (eds.). Can. Bull. Fish. Aquat. Sci., 213: 3-26.

ALVERSON, D. L. 1991. Commercial fisheries and the Steller sea lion (Eumetopias jubatus): The conflict arena. Univ. Wash. Fish. Res. Inst., Seattle, WA. 90 p.

ANDERSON, P. J., J. B. BLACKBURN, and B. A. JOHNSON. MS 1995. Historical review of smallmesh trawl sampling in the Gulf of Alaska with special reference to forage species. Prep. for Exxon Valdez oil spill restoration trustees, Apex. Proj. 29 p. (Available from National Marine Mammal Laboratory Library, NMFS, 7600 Sand Point Way NE, Seattle, WA 98115).

ANON. MS 1992. Report of the Joint ICES/NAFO Working Group on harp and hooded seals, Copenhagen, 14-18 October 1991. ICES C.M. Doc., No. Assess. $5,31 \mathrm{p}$.

MS 1994. Report of the Joint ICES/NAFO Working Group on harp and hooded seals, Copenhagen, 15-21 September 1993. ICES C.M. Doc., No. Assess. 5, 35 p.

1995. State of the environment Norway - biodiversity. UNEP GRID- Arendal, Longum Park, Norway.

APOLLONIO, S. 1994. The uses of ecosystem characteristics in fisheries management. Rev. Fish. Sci., 2: $157-180$.

BAKKALA, R. G. 1993. Structural and historical changes in the groundfish complex of the eastern Bering Sea. NOAA Tech. Rep., NMFS No. 114. 91 p.

BAKKALA, R. G., V. G. WESPESTAD, and L. LOW. 1987. Historical trends in abundance and current conditions of walleye pollock in the eastern Bering Sea. Fish. Res., 5: 199-215.

BARLOW, J. R. L. BROWNELL, Jr., D. P. DeMASTER, K. A. FORNEY, M. S. LOWRY, S. OSMEK, T. J. RAGEN, R. R. REEVES, and R. J. SMALL. 1995. U. S. Pacific marine mammal stock assessments. NOAA Tech. Mem., NMFS/SWFSC 219. 162 p.

BEAMISH, R. J. 1994. Climate change and exceptional fish production off the west coast of North America. Can. J. Fish. Aquat. Sci., 51: 2270-2291.

BEAMISH, R. J., and D. R. BOULLION.1993. Pacific salmon production trends in relation to climate. Can. J. Fish. Aquat. Sci., 50: 1002-1016.

1995. Marine fish production trends off the $\mathrm{Pa}-$ cific coast of Canada and the United States, In: Climate change and northern fish populations. R. J. Beamish (ed.), Can. Spec. Publ. Fish. Aquat. Sci., 121: 585-591.

BEDDINGTON, J. R., R. J. H. BEVERTON, and D. M. LAVIGNE. 1987. Marine mammals and fisheries. Allen and Unwin, London. 354 p.

BRAHAM, H. W., R. D. EVERITT, and D. J. RUGH. 1980. Northern sea lion decline in the eastern Aleutian Islands. J. Wildl. Mgmt., 44: 25-33.

BRODEUR, R. D., and D. M. WARE. 1992. Long-term variability in zooplankton biomass in the subarctic Pacific Ocean. Fish. Oceanogr., 1: 32-38.

1995. Interdecadal variability in the distribution and catch rates of epipelagic nekton in the Northeast Pacific Ocean. In: Climate change and northern fish populations. R. J. Beamish (ed.), Can. Spec. Publ. Fish. Aquat. Sci., 121: 329-356.

CARPENTER, S. R., J. F. KITCHELL, and J. R. HODGSON. 1985. Cascading trophic interactions and lake productivity. Bioscience, 35: 634-639.

COLE, L. C. 1954. The population consequences of life history phenomena. Quart. Rev. Biol., 29: 103-137.

COONEY, R. T., M. E. CLARKE, and P. D. WALLINE. 1980. Food dependencies for larval, post larval, and juvenile walleye pollock, Theragra chalcogramma (Pallas), in the southeastern Bering Sea, In: PROBES: Processes and resources of the Bering Sea shelf. Univ. Alaska, Inst. Mar. Sci., Fairbanks, AK., Prog. Rep., 180: 167-189.

DECKER, M. B., G. L. HUNT, Jr., and G. V. BYRD, Jr. 1995. The relationships among sea-surface temperature, the abundance of juvenile walleye pollock (Theragra chalcogramma) and the reproductive performance and diets of seabirds in the Pribilof 
Islands, southeastern Bering Sea, In: Climate change and northern fish populations. R. J. Beamish (ed.). Can. J. Fish. Aquat. Sci., 121: 425-437.

DICKIE, L. M. 1973. Management of fisheries: ecological subsystems. Trans. Am. Fish. Soc., 102: 470-480.

DWYER, A. D., K. M. BAILEY, P. A. LIVINGSTON, and M. YANG. 1986. Some preliminary observations on the feeding habits of walleye pollock (Theragra chalcogramma) in the eastern Bering Sea, based on field and laboratory measurements, In: Symp. biology, stock assessment, and management of pollock, Pacific cod, and hake in the North Pacific region. Int. North Pac. Halibut Comm., Bull. No. 45: 228-246.

ESTES, J. A. 1979. Exploitation of marine mammals: r-selection of K-strategists? J. Fish. Res. Board Can., 36: 1009-1017.

1994. Top-level carnivores and ecosystem effects: questions and approaches, In: Linking species and ecosystems. C. G. Jones and J. H. Lawton (eds.), Chapman Hall, New York, p. 151-158.

FERRERO, R. and L. W. FRITZ. 1994. Comparisons of walleye pollock, Theragra chalcogramma, harvest to Steller sea lion, Eumetopias jubatus, abundance in the Bering Sea and Gulf of Alaska. U.S. Dep. Commer., NOAA Tech. Mem., NMFS AFSC-43, 23 p.

FRANCIS, R. C. and S. R. HARE. 1994. Decadal-scale regime shifts in the large marine ecosystems of the North-east Pacific: a case of historical science. Fish. Oceanogr., 3: 279-291.

FRITZ, L. W., V. G. WESPESTAD, and J. S. COLLIE. 1993. Distribution and abundance trends of forage fishes in the Bering Sea and Gulf of Alaska, In: Is it food?: Addressing marine mammal and seabird declines. Workshop summary. Univ. Alaska, Fairbanks, AK., Alaska Sea Grant Rep., 93-01, p. 30-44.

GASKIN, D. E. 1982. The ecology of whales and dolphins. Heineman, London. 459 p.

GJØSETER, H. 1995. Pelagic fish and the ecological impact of the modern fishing industry in the Barents Sea. Arctic, 48: 267-278.

HAMRE, J. 1994. Biodiversity and exploitation of the main fish stocks in the Norwegian-Barents Sea ecosystem. Biodivers. Cons., 3: 473-492.

HARE, S. R., and R. C. FRANCIS. 1995. Climate change and salmon production in the Northeast Pacific Ocean. In: Climate change and northern fish populations. R. J. Beamish (ed.), Can. Spec. Publ. Fish. Aquat. Sci., 121: 357-372.

HARWOOD, J. 1983. Interactions between marine mammals and fisheries, In: Advances in Applied Biology. Acad. Press, London, p. 189-214.

HATCH, S. A. 1993. Population trends of Alaskan seabirds. Pac. Seabird Grp. Bull., 20: 3-12.

HOLLOWED, A. B., and W. S. WOOSTER. 1992. Variability of winter ocean conditions and strong year classes of Northeast Pacific groundfish. ICES Mar. Sci. Sym., 195: 433-444.
1995. Decadal-scale variations in the eastern subarctic Pacific: II. Response of Northeast Pacific fish stocks, In: Climate change and northern fish populations. R. J. Beamish (ed.), Can. J. Fish. Aquat. Sci., 121: 373-385.

HUNT, G. L. Jr., M. B. DECKER, and A. KITAYSKY. 1996. Fluctuations in the Bering Sea ecosystem as reflected in the reproductive ecology and diets of kittiwakes on the Pribilof Islands, 1975 to 1991. In: Aquatic predators and their prey. S. P. R. Greenstreet and M. L. Tasker (eds.), Blackwell Scientific Publ., Oxford p. 142-153.

ITO, D. H., and J. N. IANELLI. 1994. Pacific ocean perch. In: Stock assessment and fishery evaluation report for the groundfish resources of the Bering Sea/Aleutian Islands regions as projected for 1995. Bering Sea/Aleutian Island Groundfish Plan Team, North Pacific Fishery Management Council, 605 W. 4th Ave, Suite 306, Anchorage, AK 99501, 37 p.

KENYON, K. W., V. B. SCHEFFER, and D. G. CHAPMAN. 1954. A population study of the Alaskan fur-seal herd. U.S. Fish Wildlife Service, Spec. Sci. Rep., Wildl. No. 12, 77 p.

KERR, R. A. 1992. Unmasking a shifty climate system. Science, 255: 1508-1510.

KRUSE, G. H. 1993. Biological perspectives on crab management in Alaska, p.355-384. In: Proc. Int. Sym. Manage. Start. Exploit. Fish Pop; Alaska Sea Grant, AK-SG-93-02: 355-384.

KJELLQWIST, S. A., T. HAUG, and T. ØRITSLAND. 1995. Trends in age-composition, growth and reproductive parameters of Barents Sea harp seals, Phoca groenlandica. ICES J. Mar. Sci., 52: 197-208.

LAWS, R. M. 1985. The ecology of the southern ocean. Am. Sci., 73: 26-40.

LIVINGSTON, P. A. 1991. Groundfish food habits and predation on commercially important prey species in the eastern Bering Sea from 1984 to 1986. NOAA Tech. Mem., NMFS F/NWC-207, 240 p.

1993. Importance of predation by groundfish, marine mammals, and birds on walleye pollock (Theragra chalcogramma) and Pacific herring (Clupea pallasi) in the eastern Bering Sea. Mar. Ecol. Prog. Ser., 102: 205-215.

1994. Ecosystem components: trophic structure, In: Ecosystem Considerations. North Pacific Fisheries Management Council, Anchorage, AK, p. 11-26.

LIVINGSTON, P. A., A. WARD, G. M. LANG, and M. S. YANG. 1993. Groundfish food habits and predation on commercially important prey species in the eastern Bering Sea from 1987 to 1989. U.S. Dep. Commer., NOAA Tech. Mem., NMFS-AFSC-11. $192 \mathrm{p}$.

LOWE, S. A., and L. W. FRITZ. 1995. Atka mackerel. In: Stock assessment and fishery evaluation report for the groundfish resources of the Bering Sea/Aleutian Island regions as projected for 1996. Bering Sea and Aleutian Island Plan Team, North Pacific Fish- 
ery Management Council, Anchorage, AK, 59 p.

LOUGHLIN, T. R., and R. L. MERRICK. 1989. Comparison of commercial harvests of walleye pollock and northern sea lion abundance in the Bering Sea and Gulf of Alaska, In: Proc. Int. Sym.. Biol. Manage. Walleye Pollock. Alaska Sea Grant Rep., 89-1, p. 679-700.

MARGALEF, R. 1975. Diversity, stability, and maturity in natural ecosystems, In: Unifying concepts in ecology. W. H.van Dobhen and R. H. LoweMcConnell (eds.) W. Junk. B. V. Publishers, The Hague, p. 151-160.

MERRICK, R. L. 1995. The relationship of the foraging ecology of Steller sea lions (Eumetopias jubatus) to their population decline in Alaska. Ph. D. diss., Univ. Wash., Seattle, 175 p.

MERRICK, R. L., M. K. CHUMBLEY, and G. V. BYRD. 1997. A potential relationship between the diet diversity of Steller sea lions (Eumetopias jubatus) and their population decline in Alaska. Can. J. Fish. Aquat. Sci., 54: 1342-1348.

MERRICK, R. L., and D. G. CALKINS. 1996. Importance of juvenile walleye pollock in the diet of Gulf of Alaska Steller sea lions, In: Ecology of juvenile walleye pollock, Theragra chalcogramma. R. D. Brodeur, P. A. Livingston, T. R. Loughlin, and A. B. Hollowed, (eds.), NOAA Tech. Rep., NMFS 126: $153-166$.

MERRICK, R. L., T. R. LOUGHLIN, and D. G. CALKINS. 1987. Decline in abundance of the northern sea lion, Eumetopias jubatus, in Alaska, 1956-86. Fish. Bull. U.S., 85: 351-365.

MYERS, R. A., and N. J. BARROWMAN. 1996. Is fish recruitment related to spawner abundance? Fish. Bull., 94: 707-724.

NATIONAL MARINE FISHERIES SERVICE (NMFS). 1993. Final conservation plan for the northern fur seal (Callorhinus ursinus). Prep. by NMML, AFSC, NMFS, Seattle, WA, and Off. Pro. Res./NMFS, Silver Spring, MD, 80 p. (Available from National Marine Mammal Laboratory Library, NMFS, 7600 Sand Point Way NE, Seattle, WA 98115).

1995. Status review of the United States Steller sea lion (Eumetopias jubatus) population. Prep. by NMML, AFSC, NMFS, Seattle, WA 45 p. (Available from National Marine Mammal Laboratory Library, NMFS, 7600 Sand Point Way NE, Seattle, WA 98115).

NORTHRIDGE, S. P. 1991. An updated world review of interactions between marine mammals and fisheries. FAO Fish. Tech. Pap., 251: 58 p.

O'NEILL, R. V., D. L. DeANGELIS, J. B. WAIDE, and T. F. H. ALLEN. 1986. A hierarchical concept of ecosystems. Princeton Univ. Press, 312 p.

OTTO, R. S. 1989. An overview of eastern Bering Sea king and Tanner crab fisheries. In: Proc. Int. Symp. King and Tanner Crabs, Alaska Sea Grant AK-SG90-04: 9-26.

PEREZ, M. A. 1986. Estimating total consumption of walleye pollock by northern fur seals in the eastern Bering Sea using diet composition data. In: Summary of joint research on the diets of northern fur seals and fish in the Bering Sea during 1981. T. R. Loughlin and P. A. Livingston (eds.), AFSC Proc. Rep. 86-19: 31-38.

1994. Calorimetry measurements of energy value of some Alaskan fishes and squids. NOAA Tech. Mem., NMFS-AFSC-32, 32 p.

PEREZ, M. A., and M. A. BIGG. 1986. Diet of northern fur seals (Callorhinus ursinus) off western North America. Fish. Bull. U.S., 84: 957-971.

PEREZ, M. A., and T. R. LOUGHLIN. 1991. Incidental catch of marine mammals by foreign and JV trawl vessels in the U.S. EEZ of the North Pacific. NOAA Tech. Rep., NMFS 104, 57 p.

PEREZ, M. A., and W. B. McALLISTER. 1993. Estimates of food consumption by marine mammals in the eastern Bering Sea. NOAA Tech. Mem. NMFS-AFSC-14, $36 \mathrm{p}$.

PIANKA, E. R. 1970. On "r" and "K" selection. Am. Nat., 104: 592-597.

PIATT, J. F., and P. ANDERSON. 1996. Response of common murres to the Exxon Valdez oil spill and long-term changes in the Gulf of Alaska marine ecosystem. In: Exxon Valdez oil spill symposium proceedings. S. D. Rice, R. B. Spies, D. A. Wolfe, and B. A. Wright (eds.). Amer. Fish. Soc. Sym., No. 18: 720-737.

PITCHER, K. W. 1980. Stomach contents and feces as indicators of harbor seal, Phoca vitulina, foods in the Gulf of Alaska. Fish. Bull., U.S., 78: 797-798.

1981. Prey of the Steller sea lion, Eumetopias jubatus, in the Gulf of Alaska. Fish. Bull. U.S., 79: 467-472.

POLOVINA, J. J., G. T. MITCHUM, and G. T. EVANS. 1995. Decadal and basin-scale variation in mixed layer depth and the impact on biological production in the Central and North Pacific, 1960-88. Deep Sea Res., 42: 1701-1716.

RAY, G. C. 1981. The role of large organisms. In: Analysis of marine ecosystems. A. R. Longhurst (ed.). Acad. Press, New York, p. 397-413.

ROYER, T. C. 1989. Upper ocean temperature variability in the Northeast Pacific Ocean: is it an indicator of global warming? J. Geophys. Res., 94: 18175-18183.

1993. High-latitude oceanic variability associated with the 18.6-year nodal tide. J. Geophys. Res., 98: 4639-4644.

SINCLAIR, E., T. LOUGHLIN, and W. PEARCY. 1994. Prey selection by northern fur seals (Callorhinus ursinus) in the eastern Bering Sea. Fish. Bull. U.S., 92: 144-156.

SINCLAIR, E. H., G. A. ANTONELIS, B. W. ROBSON, R. R. REAM, and T. R. LOUGHLIN. 1996. Northern fur seal predation on juvenile walleye pollock. In: Ecology of juvenile walleye pollock, Theragra chalcogramma. R. D. Brodeur, P. A. Livingston, T. R. Loughlin, and A. B. Hollowed, (eds.). NOAA 
Tech. Rep., NMFS, 126: 167-178.

SMALL, R. J., and D. P. DeMASTER. 1995. Alaska marine mammal stock assessments 1995. NMFS, NMML, Seattle, WA, 93 p.

SMITH, G. B. 1981. The biology of walleye pollock. In: The eastern Bering Sea shelf: oceanography and resources, Vol I., D. W. Hood and J. A. Calder (eds.). U.S. Gov. Printing Off., Wash. D.C., p. 527-551.

SPRINGER, A. M. 1992. A review: Walleye pollock in the North Pacific. How much difference do they really make? Fish Oceanog., 1: 80-96.

STEARNS, S. C. 1976. Life-history tactics: a review of the ideas. Quart. Rev. Biol., 51: 3-47.

TABATA, S. 1989. Trends in long-term variability of ocean properties at Ocean Station $\mathrm{P}$ in the northeast Pacific Ocean. In: Aspects of climate variability in the Pacific and western Americas. D. H. Peterson (ed.), Geophys. Monogr., 55: 113-132.

TAKAHASHI, Y., and H. YAMAGUCHI. 1972. Stock of the Alaska pollock in the eastern Bering Sea. Bull. Japanese Soc. Sci. Fish., 38: 389-399 (in Japanese, English summary).

TOMILIN, A. G. 1957. Mammals of the U.S.S.R. and adjacent countries. Vol. 9 Cetacea. Izd. Akad. Nauk. SSR, Moscow, 756 p. (in Russian, Transl. by Isr. Prog. Sci. Transl., 1967).

TRENBERTH, K. E., and J. W. HURRELL. 1995. Decadal coupling atmospheric-ocean variations in the North Pacific Ocean. In: Climate change and northern fish populations. R. J. Beamish (ed.). Can. Spec. Publ. Fish. Aquat. Sci., 121: 15-24.

VENRICK, E. L. 1995. Scales of variability in a stable environment: Phytoplankton in the central North Pacific. Chapter 10. In: Ecological time series. T. M. Powell and J. H. Steele (ed.). Chapman Hall, New York, p. 121-140.
VENRICK, E. L., J. A. McGOWAN, D. R. CAYAN, and T. L. HAYWARD. 1987. Climate and chlorophyll $a$ : Long-term trends in the central north Pacific Ocean, Sci., 238: 70-72.

WALLINE, P. D. 1983. Growth of larval and juvenile walleye pollock related to year class strength. Ph. D. diss., Univ. Wash., Seattle, 144 p.

WESPESTAD, V. G. 1991. Pacific herring population dynamics, early life history, and recruitment variation relative to eastern Bering Sea oceanographic factors. Ph. D. dissertation. Univ. Wash., Seattle, $237 \mathrm{p}$.

1994. Walleye pollock. In: Stock assessment and fishery evaluation report for the groundfish resources of the Bering Sea/Aleutian Island regions as projected for 1995. Bering Sea and Aleutian Island Plan Team, North Pacific Fishery Management Council, Anchorage, AK, 29 p.

WESPESTAD, V. G., and S. M. FRIED. 1983. Review of the biology and abundance trends of Pacific herring (Clupea harengus pallasi). In: From year to year: Interannual variability of the environment and fisheries of the Gulf of Alaska and the eastern Bering Sea. W. S. Wooster (ed.). WA Sea Grant Publ., WSG-WO-83-3: 17-29.

WOOSTER, W., and A. HOLLOWED. 1995. Decadalscale variations in the eastern subarctic $\mathrm{Pa}$ cific. I. Winter ocean conditions, In: Climate change and northern fish populations. R. J. Beamish (ed.). Can. Spec. Publ. Fish. Aquat. Sci., 121: $81-85$.

YORK, A. E., and J. R. HARTLEY. 1981. Pup production following harvest of female northern fur seals. Can. J. Fish. Aquat. Sci., 38: 84-90.

YORK, A. E., and P. KOZLOFF. 1987. On the estimation of numbers of northern fur seals. Can. J. Fish. Aquat. Sci., 38: 84-90. 